\title{
Effect of Intercropping Systems on Yield Attributes and Yield of Pearlmillet with Grain Legumes under Rainfed Conditions
}

\author{
B. Triveni*, A. Muneendra Babu, G. Prabhakara Reddy and V. Munaswamy \\ Department of Agronomy, S. V. Agricultural College, Tirupati-517502, A.P., India \\ *Corresponding author
}

A B S T R A C T

\begin{abstract}
Keywords
Pearlmillet,

Groundnut, Legume,

Yield attributes and

Yield.

Article Info

Accepted:

26 September 2017

Available Online:

10 November 2017

A field experiment was conducted during kharif, 2015 at S.V. Agricultural College Farm, Tirupati to study the effect of intercropping systems on yield attributes and yield of pearlmillet. The results revealed that sole pearlmillet planted at $45 \mathrm{~cm} \mathrm{x} 12 \mathrm{~cm}\left(\mathrm{~T}_{1}\right)$ produced higher yield attributes, grain and stover yields of pearlmillet. On comparison of intercropping systems, it was observed that, all the yield attributes were higher with pearlmillet + cowpea in 2:2 Paired row spacing $\left(\mathrm{T}_{4}\right)$, while these parameters were highest with pearlmillet + groundnut in 1:1 Uniform row spacing $\left(\mathrm{T}_{5}\right)$.
\end{abstract}

\section{Introduction}

Pearlmillet is an important crop grown for food and fodder for human and livestock population in dryland areas. Pearlmillet cultivation is mostly confined to rainfed lands, poor and impoverished soils. So, growing of pearlmillet as a sole crop under this situation is risky and uneconomical (Itnal and Yandagoudar, 1990). It is a fast growing short duration crop which has high biomass production potential. The bulk of pearlmillet grain produced in Chittoor district is utilized in poultry feed as poultry, an important enterprise in this district. Recently, the pearlmillet is gaining importance as the nutritionists recommended adding millets in the Indian diet to combat malnutrition as millets are rich source of minerals. Intercropping is a system of growing of two or more crops simultaneously on the same piece of land in a distinct row arrangement which may not be necessarily be sown and harvested exactly at the same time but they are virtually simultaneous for a significant part of the growing period (Willey, 1979).

\section{Materials and Methods}

A field experiment was carried out during kharif, 2015 at S.V. Agricultural College Farm, Tirupati. The experimental soil was sandy loam in texture, slightly acidic in soil reaction, low in available nitrogen and medium in organic carbon, available phosphorus and available potassium. The experiment was laid out in a Randomized Block Design with eight treatments and 
replicated thrice. The treatments comprised of sole pearlmillet planted at $45 \mathrm{~cm} \mathrm{x} 12 \mathrm{~cm}$ $\left(\mathrm{T}_{1}\right)$, sole pearlmillet in paired row spacing $40 / 80 \mathrm{~cm}\left(\mathrm{~T}_{2}\right)$, pearlmillet + cowpea in $1: 1$ uniform row spacing (URS) $\left(\mathrm{T}_{3}\right)$, pearlmillet + cowpea in 2:2 paired row spacing (PRS) $\left(\mathrm{T}_{4}\right)$, pearlmillet + groundnut in 1:1 uniform row spacing (URS) $\left(\mathrm{T}_{5}\right)$, pearlmillet + groundnut in 2:2 paired row spacing (PRS) $\left(\mathrm{T}_{6}\right)$, pearlmillet + greengram in 1:1 uniform row spacing (URS) $\left(\mathrm{T}_{7}\right)$, pearlmillet + greengram in 2:2 paired row spacing (PRS) $\left(\mathrm{T}_{8}\right)$. The hybrid and varieties tested in this experiment were ABH-1 (Pearlmillet), TPTC29 (Cowpea), Dharani (Groundnut) and LGG - 460 (Greengram). Sole crop of pearlmillet was sown at $45 \mathrm{~cm} \times 12 \mathrm{~cm}$ and in paired rows at $40 / 80 \mathrm{~cm}$ with an intra-row spacing of $10 \mathrm{~cm}$. While under intercropping systems, pearlmillet was sown at $60 \mathrm{~cm} \times 10 \mathrm{~cm}$ in $1: 1$ ratio and in paired rows of $40 / 80 \mathrm{~cm}$ in $2: 2$ ratio with an intra-row spacing of $10 \mathrm{~cm}$. Two rows of intercrops viz., cowpea, groundnut and greengram were sown at $30 \mathrm{~cm} \times 10 \mathrm{~cm}$ in between paired rows of pearlmillet in 2:2 ratio, while in 1:1 ratio the intercrops cowpea, groundnut and greengram were sown at $60 \mathrm{~cm}$ $\mathrm{x} 10 \mathrm{~cm}$ in between the pearlmillet rows. The recommended dose of $60 \mathrm{~kg} \mathrm{~N}, 30 \mathrm{~kg} \mathrm{P}_{2} \mathrm{O}_{5}$ and $20 \mathrm{~kg} \mathrm{~K}_{2} \mathrm{O}$ ha $^{-1}$ was applied through urea, single super phosphate and muriate of potash for pearlmillet, $20 \mathrm{~kg} \mathrm{~N}, 50 \mathrm{~kg} \mathrm{P}_{2} \mathrm{O}_{5} \mathrm{~kg} \mathrm{ha}^{-1}$ for cowpea and greengram and $20 \mathrm{~kg} \mathrm{~N}, 40$ $\mathrm{kg} \mathrm{P}_{2} \mathrm{O}_{5}$ and $50 \mathrm{~K}_{2} \mathrm{O} \mathrm{kg} \mathrm{ha}{ }^{-1}$ for groundnut respectively. For pearlmillet, entire dose of phosphorous, potassium and half of the dose of nitrogen were applied as basal at the time of sowing and the remaining half of the nitrogen was top dressed at 30 DAS.

\section{Results and Discussion}

The results obtained from the present investigation as well as relevant discussion have been summarized under following heads.

\section{Yield attributes of pearlmillet}

Maximum yield attributes like grain weight earhead $^{-1}$, length of the earhead and thousand grain weight were highest with sole pearlmillet planted at $45 \mathrm{~cm} \times 12 \mathrm{~cm}\left(\mathrm{~T}_{1}\right)$, which was closely followed by sole pearlmillet in paired row spacing of $40 / 80 \mathrm{~cm}$ $\left(\mathrm{T}_{2}\right)$. On comparison of different intercropping systems, it was observed that, all the yield attributes were maximum with pearlmillet + cowpea in 2:2 PRS $\left(\mathrm{T}_{4}\right)$. While these parameters were lowest with pearlmillet + groundnut in 1:1 uniform row spacing $\left(\mathrm{T}_{5}\right)$. This might be due to minimum competition from cowpea for water, nutrients and light. Similar results were reported earlier by Parmar (1989), Ramulu et al., (1998) and Singh and Singh (2001).

\section{Yield of Pearlmillet and intercrops}

The maximum grain yield obtained under sole pearlmillet planted at $45 \mathrm{~cm} \times 12 \mathrm{~cm}$ could be on account of more evenly distributed plants per unit area and better canopy coverage and lack of competition from intercrops (Table 1).

Among the intercrops, groundnut in 1:1 URS offered greater competition to pearlmillet crop and resulted in lowest pearlmillet grain yield (Table 2). Even among intercrops, groundnut was more aggressive as component crop and decreased the grain yield of pearlmillet, whereas cowpea as an intercrop offered least competition to pearlmillet which resulted in maximum grain yield (Table 3 ). The results are corroborating with the findings of Yadav and Yadav (2001), Kumar et al., (2006) and Choudhary (2009). Perusal of the data revealed that sole pearlmillet $\left(\mathrm{T}_{1}\right)$ produced maximum stover yield of $3799 \mathrm{~kg} \mathrm{ha}^{-1}$ followed by sole pearlmillet in paired row spacing of $40 / 80 \mathrm{~cm}\left(\mathrm{~T}_{2}\right)\left(3665 \mathrm{~kg} \mathrm{ha}^{-1}\right)$ and both the treatments were significantly superior to other planting systems. 
Table.1 Yield attributes and yield of pearlmillet at harvest as influenced by pearlmillet + legume intercropping

\begin{tabular}{|c|c|c|c|c|c|c|}
\hline Treatments & $\begin{array}{l}\text { Number of } \\
\text { earheads } \\
\text { hill }^{-1}\end{array}$ & $\begin{array}{l}\text { Length of } \\
\text { the earhead } \\
\text { (cm) }\end{array}$ & $\begin{array}{l}\text { Grain weight } \\
\text { earhead }^{-1}(\mathrm{~g})\end{array}$ & $\begin{array}{l}\text { Thousand } \\
\text { grain weight } \\
\text { (g) }\end{array}$ & $\begin{array}{l}\text { Grain yield } \\
\left(\mathrm{kg} \mathrm{ha}^{-1}\right)\end{array}$ & $\begin{array}{l}\text { Stover yield } \\
\left(\mathrm{kg} \mathrm{ha}^{-1}\right)\end{array}$ \\
\hline $\mathrm{T}_{1}$ : Sole pearlmillet $(45 \mathrm{~cm} \times 12 \mathrm{~cm})$ & 2.5 & 25.4 & 14.3 & 8.5 & 1661 & 3799 \\
\hline $\mathrm{T}_{3}$ : Pearlmillet + cowpea in $1: 1$ URS & 2.1 & 24.2 & 12.4 & 8.3 & 1540 & 2927 \\
\hline $\mathrm{T}_{4}:$ Pearlmillet + cowpea in $2: 2$ PRS & 2.3 & 25.2 & 13.1 & 8.4 & 1615 & 3115 \\
\hline $\mathrm{T}_{5}$ : Pearlmillet + groundnut in $1: 1 \mathrm{URS}$ & 1.7 & 23.3 & 11.7 & 8.4 & 1465 & 2485 \\
\hline $\mathrm{T}_{6}$ : Pearlmillet + groundnut in 2:2 PRS & 2.1 & 24.2 & 11.9 & 8.5 & 1509 & 2905 \\
\hline $\mathrm{T}_{7}$ : Pearlmillet + greengram in $1: 1 \mathrm{URS}$ & 1.8 & 24.0 & 12.1 & 8.4 & 1490 & 2692 \\
\hline $\mathrm{T}_{8}$ : Pearlmillet + greengram in $2: 2 \mathrm{PRS}$ & 2.1 & 24.3 & 12.5 & 8.5 & 1580 & 3015 \\
\hline SEm \pm & 0.15 & 0.10 & 0.37 & 0.07 & 40.0 & 128.6 \\
\hline $\mathrm{CD}(\mathrm{P}=0.05)$ & 0.4 & 0.3 & 1.1 & NS & 123 & 393 \\
\hline
\end{tabular}

Table.2 Yield attributes and yield of intercrops at harvest as influenced by pearlmillet + legume intercropping

\begin{tabular}{|c|c|c|c|c|c|c|c|c|}
\hline Treatments & $\begin{array}{l}\text { No. of } \\
\text { branches } \\
\text { plant }^{-1}\end{array}$ & $\begin{array}{l}\text { No. of } \\
\text { clusters } \\
\text { plant }^{-1}\end{array}$ & $\begin{array}{l}\text { No. of } \\
\text { pods } \\
\text { cluster }^{-1}\end{array}$ & $\begin{array}{ll}\text { No. of } \\
\text { seeds } \\
\text { pod }^{-1}\end{array}$ & $\begin{array}{l}\text { Length of } \\
\text { the pod } \\
\text { (cm) }\end{array}$ & $\begin{array}{l}\text { Test } \\
\text { weight } \\
\text { (g) }\end{array}$ & $\begin{array}{l}\text { Seed } \\
\text { yield } \\
\left(\mathrm{kg} \mathrm{ha}^{-1}\right)\end{array}$ & $\begin{array}{l}\text { Haulm } \\
\text { yield } \\
\left(\mathrm{kg} \mathrm{ha}^{-1}\right)\end{array}$ \\
\hline Sole cowpea & 4.8 & 4.7 & 4.3 & 14.0 & 19.8 & 19.4 & 690 & 1926 \\
\hline Sole greengram & 4.2 & 11.7 & 9.3 & 5.5 & 9.8 & 32.3 & 625 & 1459 \\
\hline Pearlmillet + cowpea in 1:1 URS & 3.9 & 3.5 & 3.6 & 13.1 & 18.5 & 18.2 & 450 & 1495 \\
\hline Pearlmillet + cowpea in 2:2 PRS & 4.7 & 3.7 & 3.7 & 13.3 & 18.9 & 19.2 & 475 & 1558 \\
\hline Pearlmillet + greengram in 1:1 URS & 4.0 & 10.0 & 8.1 & 5.1 & 9.2 & 27.6 & 379 & 1151 \\
\hline Pearlmillet + greenmgram in 2:2 PRS & 3.9 & 11.0 & 8.3 & 5.2 & 9.5 & 28.5 & 390 & 1220 \\
\hline
\end{tabular}


Table.3 Yield attributes and yield of groundnut as influenced by pearlmillet+ legume intercropping

\begin{tabular}{|c|c|c|c|c|c|c|c|}
\hline Treatments & $\begin{array}{l}\text { No. of } \\
\text { branch } \\
\text { es } \\
\text { plant }^{-1}\end{array}$ & $\begin{array}{l}\text { No. of } \\
\text { filled } \\
\text { pods } \\
\text { plant }^{-1}\end{array}$ & $\begin{array}{l}\text { No. of } \\
\text { unfilled } \\
\text { pods } \\
\text { plant }^{-1}\end{array}$ & $\begin{array}{l}\text { Total no. } \\
\text { of pods } \\
\text { plant }^{-1}\end{array}$ & $\begin{array}{l}\text { Test } \\
\text { weight } \\
\text { (g) }\end{array}$ & $\begin{array}{l}\text { Pod } \\
\text { yield } \\
\left(\mathrm{kg} \mathrm{ha}^{-1}\right)\end{array}$ & $\begin{array}{l}\text { Haulm } \\
\text { yield } \\
\text { (kg ha } \\
\text { 1) }\end{array}$ \\
\hline Sole groundnut & 5.0 & 18.7 & 7.3 & 26.0 & 34 & 1263 & 2247 \\
\hline $\begin{array}{l}\text { Pearlmillet + groundnut in } \\
1: 1 \text { URS }\end{array}$ & 4.7 & 15.5 & 6.5 & 22.0 & 32 & 885 & 1645 \\
\hline $\begin{array}{l}\text { Pearlmillet }+ \text { groundnut in } \\
2: 2 \text { PRS }\end{array}$ & 4.8 & 16.7 & 7.0 & 23.7 & 32 & 951 & 1867 \\
\hline
\end{tabular}

Among the intercropping systems, pearlmillet + cowpea in 2:2 PRS $\left(\mathrm{T}_{4}\right)$ produced maximum stover yield of pearlmillet $\left(3115 \mathrm{~kg} \mathrm{ha}^{-1}\right)$ and was on par with pearlmillet + greengram in 2:2 PRS $\left(\mathrm{T}_{8}\right)\left(3015 \mathrm{~kg} \mathrm{ha}^{-1}\right)$, pearlmillet + cowpea in 1:1 URS $\left(\mathrm{T}_{3}\right)\left(2927 \mathrm{~kg} \mathrm{ha}^{-1}\right)$ and pearlmillet + groundnut in 2:2 PRS $\left(\mathrm{T}_{6}\right)(2905$ $\left.\mathrm{kg} \mathrm{ha}{ }^{-1}\right)$. Pearlmillet gave the lowest stover yield of $2485 \mathrm{~kg} \mathrm{ha}^{-1}$ with pearlmillet + groundnut in 1:1 URS $\left(\mathrm{T}_{5}\right)$. The stover yield of pearlmillet was reduced in all the intercropping systems compared to sole crop of pearlmillet. The reduction was more prominent in intercropping systems in 1:1 ratio than in 2:2 ratio. This clearly indicated that pearlmillet was subjected to greater competition from intercrops in 1:1 ratio as compared to 2:2 ratio. Lower grain and stover yields of pearlmillet were noticed when pearlmillet was intercropped with cowpea, groundnut and greengram at 1:1 uniform row spacing, which might be due to higher competition offered by the intercrops for natural resources like space, plant nutrients, moisture and incoming solar radiation in 1:1 URS compared to 2:2 PRS. Under 1:1 URS, the competition from intercrops was on both sides of pearlmillet rows, where as in 2:2 PRS, the competition was on one side of the pearlmillet paired rows only. This resulted in lower grain and stover yields of pearlmillet in intercropping systems in 1:1 URS as compared to $2: 2 \mathrm{PRS}$. The results are in agreement with the findings of Kulkarni and Sojitra (1986), Parmar (1989), Choudhary (2009), Yadav and Yadav (2001), Kumar et al., (2006), Choudhary (2009) and Ghilotia et al., (2015).Yield attributes, seed and haulm yields of intercrops viz., cowpea, groundnut and greengram were maximum when grown as sole crops followed by intercropping of legumes with pearlmillet in 2:2 paired row spacing and 1:1 uniform row spacing in order of descent.

Sole pearlmillet planted at $45 \mathrm{~cm} \mathrm{x} 12 \mathrm{~cm}$ recorded higher yield attributes and yield than other planting systems. Among the intercropping systems, pearlmillet + cowpea in 2:2 paired row spacing results in higher yield attributes and yield of pearlmillet and intercrops as compared to other intercropping systems in sandy loam soils of Tirupati.

\section{References}

Choudhary, R.A. 2009. Intercropping in pearlmillet [Pennisetum glaucum (L.) R.Br.Emend.Stuntz] with pluse crops in rainfed conditions. M. Sc. (Agri.) Thesis submitted to the Sardar Krushinagar Dantiwada Agricultural University, Sardar Krushinagar, Gujarat, India.

Ghilotia, Y.K., Meena, R.N and Lakhapati Singh. 2015. Pearlmillet and mungbean intercropping as influenced by various 
row ratio sunder custard apple orchard of vindhyan region. The Bio scan.10(1):87-91.

Itnal, C.J and Yandagoudar, S. A. 1990. Bajra based intercropping systems. In proceedings of summer short course on intercropping principles and practices. 7-16 May, 1990. Department of Agronomy, UAS, Dharwad, Karnataka, India. pp. 68 - 73.

Kulkarni, J. H and Sojitra, V.K. 1986. Nodulation, growth and pod yield of groundnut under six intercropping systems. Madras Agricultural Journal. 73(7):366-369.

Kumar, R., Hooda, R.S., Singh, $\mathrm{H}$ and Nanwal, R.K. 2006. Performance of intercropping and strip cropping systems of pearlmillet-legume association. Indian Journal of Agronomy. 76(5):319-321.

Parmar, G.M. 1989. Intercropping in pearlmillet with different grain legume sand oilseed crop under rainfed conditions. M.Sc. (Agri.) Thesis submitted to the Sardar Krushinagar,
Gujarat Agricultural University, Gujarat.

Ramulu,V., Gautam, R. candkaushik, S.K. 1998. Intercropping in pearlmillet (Pennisetum glaucum) with grain legume sand oil seed crop sunder rainfed conditions. Indian Journal of Agronomy. 43(3):382-386.

Singh,V. P and Singh, V.K. 2001. Productivity potential and economics of maize (Zea mays 1.) And soybean (Glycine max) intercropping pattern sunder rainfed low hill or valley situation of Uttaranchal. Indian Journal of Agronomy. 46(1):27-31.

Willey, R.W. 1979. Intercropping - its importance and research needs. Part I. Competition and yield advantage. Field Crops Abstract. 32 (1): 1- 10.

Yadav, R.S and Yadav, O.P. 2001. The performance of cultivar of pearlmillet and clusterbean under sole cropping and intercropping systems in arid zone conditions in India. Experimental Agriculture. 37 (2): 231 - 240.

\section{How to cite this article:}

Triveni, B., A. Muneendra Babu, G. Prabhakara Reddy and Munaswamy, V. 2017. Effect of Intercropping Systems on Yield Attributes and Yield of Pearlmillet with Grain Legumes under Rainfed Conditions. Int.J.Curr.Microbiol.App.Sci. 6(11): 3567-3571. doi: https://doi.org/10.20546/ijcmas.2017.611.418 